\title{
O abandono da docência por professoras universitárias iniciantes
}

\section{Abandonment of teaching by beginner university teachers}

\author{
Mauro Volney GIULIATO' \\ Nadiane FELDKERCHER ${ }^{2}$
}

\begin{abstract}
Resumo
No trabalho objetivamos compreender os motivos do abandono da docência das professoras iniciantes na educação superior. A pesquisa, qualitativa e empírica, utilizou entrevistas para a coleta de dados junto a cinco ex-professoras com até cinco anos de experiência na docência superior, as quais se desligaram da profissão por adversidades profissionais e pessoais. $\mathrm{O}$ abandono docente é o fim de um longo processo de lutas que envolve múltiplas intercorrências, relacionadas ao nível pessoal, profissional e institucional. Ressaltamos a importância do acompanhamento do ingresso na carreira e de açóes formativas que contribuam com a construção de identidades docentes e ambientes de trabalho favoráveis.
\end{abstract}

Palavras-chave: Abandono docente. Educaçáo superior. Professoras iniciantes. Pedagogia universitária.
Abstract

In the work we aim to understand the reasons for the abandonment of teaching by teachers beginning in higher education. The research, qualitative and empirical, used interviews for data collection with five former teachers with up to five years of experience in higher education, who left the profession due to professional and personal adversities. Teacher abandonment is the end of a long process of struggles that involves multiple complications, related to the personal, professional and institutional level. We emphasize the importance of monitoring career entry and training actions that contribute to the construction of teaching identities and favorable work environments.

Keywords: Teacher abandonment. Higher Education. Beginning teachers. University Pedagogy.

1 Mestre em Educação. Psicólogo. Psicólogo clínico em Concórdia - Santa Catarina. Integrante do Grupo de Pesquisa Formação Docente e Práticas de Ensino, vinculado ao Programa de Pós-graduação em Educação da Universidade do Oeste de Santa Catarina. Lattes: http://lattes.cnpq.br/4408260833549879. ORCID: https://orcid.org/0000-0002-0703-230X. E-mail: maurogiuliato@hotmail.com

2 Doutora em Educação. Pedagoga. Professora do Departamento de Teoria e Prática da Educação da Universidade Estadual de Maringá, em Maringá - Paraná. Integrante do Grupo de Pesquisa Formação Docente e Práticas de Ensino (PPGEd-Unoesc). Lattes: http://lattes.cnpq.br/0523940598025411. ORCID: http://orcid.org/0000-0002-8208-3369. E-mail: nadianef@gmail.com 


\section{O início da docência universitária e seus percalços}

Quais os motivos do abandono da docência das professoras iniciantes na educação superior? Essa foi a pergunta que nos motivou no desenvolvimento desse trabalho. Para respondê-la, apresentamos na primeira seção as bases teóricas e as escolhas metodológicas da pesquisa, na segunda seção os resultados e análises da investigação e, na terceira e última seção as consideraçóes finais sobre o questionamento.

Consideramos necessário e importante identificar os motivos do abandono da docência universitária por parte de professoras em início da carreira para poder compreender as dinâmicas da docência, seus entrecruzamentos, seus limites, suas motivaçôes e suas necessidades. Os motivos do abandono ajudam, ainda, a pensar e propor açóes formativas para os docentes em atuação, especialmente os que se encontram no início da carreira, na intenção de fortalecer suas identidades, suas práticas e qualificar os processos educativos.

Justificamos o desenvolvimento da investigação por identificarmos poucas pesquisas tanto sobre o ingresso no magistério quanto sobre o abandono docente, por compreendermos que as dimensóes pessoal e profissional dos professores são indissociáveis, por entendermos que o abandono docente acarreta na qualidade dos processos educativos, por defendermos condiçóes de trabalho favoráveis aos docentes e por acreditarmos no potencial formativo e autoconfiante dos programas de formação docente.

Muitas vezes, a formação específica para o exercício da docência dos docentes que atuam na educação superior é frágil. O título de doutorado ou de mestrado costuma ser um dos pré-requisitos para o ingresso e exercício de qualquer vaga oferecida na docência na educação superior - o que se assemelha com o que é preconizado pela Lei de Diretrizes e Bases da Educação - LDB (BRASIL, 1996) de que neste nível de ensino tenha-se pelo menos 1/3 dos seus docentes pós-graduados em cursos stricto sensu. Tais cursos, como sabemos, enfatizam uma formação voltada à pesquisa e aos conhecimentos da área específica de formação.

Este fato faz com que, via de regra,

a entrada na docência apresenta como característica marcante a falta de preparação específica para este nível de ensino. [...] os professores em início da carreira náo estáo preparados para atuarem no nível de ensino em que se encontram. Advém daí a indagação: quem forma ou como se formam estes docentes? (ISAIA; MACIEL; BOLZAN, 2010, p. 3) 
Estas são algumas das indagaçôes frequentes dos estudos no campo da pedagogia universitária que revelam que, muitas vezes, são limitados os conhecimentos referentes à didática por parte dos profissionais que se iniciam no magistério superior. Além de apresentarem estas indagaçôes, as pesquisas da área também defendem que a "qualidade do ensino superior está na preparação, tanto no campo específico como no campo pedagógico" (PIMENTA; ANASTASIOU, 2002, p. 35).

Entáo, quando profissionais de distintas áreas ingressam na docência superior, iniciam também um ciclo profissional, compreendido em distintos "momentos da carreira docente, envolvendo trajetória vivencial dos professores e o modo como eles articulam o pessoal, o profissional e o institucional e, consequentemente, como vão se (trans)formando no decorrer do tempo" (ISAIA; MACIEL; BOLZAN, 2010, p. 1). Tais movimentos carregam as idiossincrasias de cada sujeito específico, além de serem influenciados pela forma como o indivíduo interpreta os acontecimentos por ele experimentados (ISAIA; MACIEL; BOLZAN, 2010). Ou seja, o desenvolvimento profissional e a construção identitária dos docentes universitários ocorre com e na própria prática profissional bem como por meio de programa formativos específicos.

No exercício da docência superior são demandadas aos profissionais distintas atividades que envolvem o ensino, a pesquisa, a extensão e a gestáo. Mesmo que o ensino seja entendido como um encargo obrigatório desenvolvido pelos docentes universitários, na esmagadora maioria das vezes é renegada para um patamar inferior a pesquisa (ALMEIDA, 2018).

Conforme indicado pela literatura especializada (PIMENTA; ANASTASIOU, 2002), a escolha pela atuação docente em nível superior se dá, muitas vezes, pelo interesse na pesquisa. A pesquisa é uma atividade escolhida ou fortemente desejada por muitos dos profissionais que ingressam na docência universitária. Talvez por dar maior visibilidade ao profissional. Talvez por ser menos desgastante se comparada às várias demandas das atividades de ensino que, muitas vezes, são desenvolvidas com ênfases em conteúdos distintos daqueles estudados pelo docente em suas investigaçóes.

Outro fato que chama a atenção quanto ao destaque da pesquisa é o argumento de que

a progressão na docência pelo desempenho acadêmico atribui muitas vezes uma pontuação maior à produção intelectual em detrimento às atividades de ensino mesmo sabendo que o ensino é o eixo central do trabalho do professor e que esse trabalho é desenvolvido em uma instituição de ensino. (FELDKERCHER, 2016, p. 226)

Assim, é possível que, muitas vezes, tanto o ingresso quanto a permanência e progressão na carreira do magistério superior sejam motivados pela pesquisa, 
afinal doutores de distintas áreas formam-se pesquisadores e, com esta titulação, tornam-se professores da educação superior. Os conhecimentos e a formaçáo voltados à docência são, na maioria das vezes, desenvolvidos no próprio exercício profissional, através de formação continuada e da própria prática de ensino.

Acrescido aos fatos acima relatados que sobrecarregam e esgotam física e mentalmente o docente universitário, este ainda constantemente e invariavelmente, está sujeito aos cortes de verbas para pesquisa, ao sucateamento estrutural das universidades e a uma cultura que reiteradamente ataca, diminuindo os logros da educação superior. Estes ataques parecem também reiterar um projeto de Estado comprometido com o mercado, que sobrecarrega o docente e o faz adoecer. Estes projetos de educação vinculados ao mercado podem ser observados em muitas instituiçóes de ensino superior privadas que, atualmente, configuram-se como empresas detentoras de grandes capitais, as quais ampliam seu monopólio rumo à expansão (por vezes pouco criteriosa) dos cursos oferecidos (BERNARDO, 2006), sendo muitos deles ofertados na modalidade à distância.

Outro aspecto que evidencia a mercantilizaçáo das universidades diz respeito às avaliaçóes dos docentes, que começam a ser avaliados a partir de um modelo que toma como base a produtividade. O profissional assume uma rotina de trabalho intensificada, que lhe exige a entrega incessante de resultados quantitativos. Desse modo, nota-se "uma supervalorização da produtividade, cujos critérios de eficiência e competitividade se equiparam à lógica de mercado" (HOFFMANN; ZANINI; MOURA; MACHADO, 2019, p. 5).

Além disso, nota-se certa precarização das condições de trabalho docente. É comum observarmos a contrataçấo de professores aulistas ou temporários, sem forte e restrito vínculo com a instituição de ensino. Diante desse contexto desfavorável, que exige a busca pela complementação de renda em outro trabalho, o interesse pela prática docente vai se deteriorando. Essa deterioração do trabalho pode avançar até o ponto em que o professor decide por abandonar a docência, visto que seus benefícios não compensam o desfavorável contexto de sua atuaçáo (BERNARDO, 2006).

A aproximaçáo com o mercado e seus resultados, especialmente presente nas instituiçóes de ensino privadas, traz o argumento de que

[o professor] deve se adaptar às demandas que surgem em consequência de tais medidas, como o aumento do número de alunos na classe, [...] demandas por serviços de cunho burocrático e operacional dadas pela estrutura física e de recursos humanos precárias, provocadas pelo intenso processo expansão. (HOFFMANN; ZANINI; MOURA; MACHADO, 2019, p. 5) 
Já Cislaghi (2011, p. 171), destaca que todas estas "alteraçóes na natureza do trabalho docente é a que transforma o professor em um empreendedor". O "professor empreendedor" representa a busca por resultados focados em quantidades, a exigência por altos e rápido índices de flexibilidade e mudança rápida, os prazos reduzidos. Representa também um professor subjugado a avaliaçóes de produtividade que incitam a competitividade e o mal estar, resultando em sobrecarga e pouca felicidade.

As razóes do mal estar e da felicidade gerados pelo trabalho docente são as mais diversas. Acreditamos que a falta da felicidade relativa ao trabalho gera o mal estar. Ainda,

diversos estados e experiências podem produzir felicidade. Alguns exemplos são: o amor, a alegria, a saúde, a saciedade, o prazer sexual, o contentamento, a segurança e a serenidade. Emoções como tristeza, medo, raiva e nojo, além de estados afetivos como ansiedade, angústia, dor e sofrimento, costumam diminuir a felicidade [...] 'felicidade' é a expressão que traduz a compreensão coerente e lúcida do mundo; ou seja: a felicidade autêntica requer uma maneira coerente de viver. Isso inclui todos os processos humanos que regulam os aspectos sexuais, materiais, emocionais, intelectuais e espirituais da vida. [...] tais aspectos (sexo, posses materiais, poder, relaçóes interpessoais, entre outros) podem ser adaptativos ou náo, a depender do grau de consciência que as pessoas têm de seus objetivos e valores. [...] o grau de coerência dos pensamentos e relacionamentos humanos pode ser medido em termos de quanto estes seriam capazes de conduzir à harmonia e à felicidade. (FERRAZ, TAVARES; ZILBERMAN, 2007, p. 236)

Independentemente dos elementos que condicionam a felicidade, há sempre uma relaçáo inerente entre a prática profissional de um indivíduo e a coerência dessa com seus objetivos e interesses pessoais. Mesmo que condicionem sua felicidade a elementos distintos, essa poderá ser alcançada apenas se posta em condição de coerência com os objetivos previamente estabelecidos.

Ao analisar a docência, percebemos que os elementos comumente apontados como potencializadores da felicidade - como as boas condiçóes de trabalho, remuneração, coerência entre exigências institucionais e interesses pessoais ... algumas vezes não são evidentes nessa atuação. A ausência desses elementos pode levar a falta de felicidade que, quando não superada, pode acarretar na desistência do magistério. Ou seja, o abandono docente também pode ser compreendido à luz da perda potencial da felicidade desses profissionais, em decorrência do contexto em que se encontram inseridos. 
O abandono docente pode ocorrer em qualquer fase da carreira deste profissional. A carreira é composta por aprendizagens, desafios, surpresas, alegrias e demandas que são vivenciados e enfrentados de modos distintos por cada profissional. Mas acreditamos que na fase do início da carreira docente, nos primeiros anos do exercício profissional essas experiências são vivenciadas de modo mais intenso, visto a dinâmica do novo, do desconhecido e das inseguranças presentes nesta fase.

Nunes e Cardoso (2013), a partir de um levantamento de publicaçóes brasileiras sobre os professores iniciantes argumentam que a temática é ainda incipiente nas pesquisas do campo da formação de professores - o que reforça o desenvolvimento de mais estudos sobre. As autoras marcam ainda que a indução é uma etapa importante e complexa no âmbito do desenvolvimento profissional docente.

A inserção na docência para aqueles profissionais que tiveram uma formação voltada à pesquisa é marcada por intensas aprendizagens sobre o ser professor, sobre os fazeres pedagógicos. É na inserção profissional destes docentes que eles se socializam profissionalmente, aprendem o ofício e, sobretudo, descobrem seus recursos e limites pedagógicos. Essas primeiras experiências profissionais originam suas primeiras impressóes, positivas ou negativas, e servem de alicerce para o desenvolvimento profissional docente.

Com base nos estudos de Jordell, Marcelo García (1999) explora a questão da socializaçáo de novos professores a partir de quatro níveis gerais de influência. É proposto que os professores iniciantes tenham sua socialização pautada a partir das seguintes dimensóes: pessoal, institucional, da classe e social. Tais dimensóes se intercruzam, e o produto de suas relaçôes determina a qualidade dessa relação (MARCELO GARCÍA, 1999).

O nível de influência "pessoal" é definido pelas experiências biográficas pregressas do sujeito, bem como pela experiência vivenciada no momento de sua formação para ser professor. Nesse contexto, nota-se uma influência que é interiorizada por meio da construção de teorias implícitas que, muito facilmente, emanam na prática concreta (MARCELO GARCÍA, 1999). O segundo nível, "da classe", diz respeito à influência exercida pelos alunos em contato com o novo docente, somados a outros elementos que configuram o ensino, como a simultaneidade, a multidimensionalidade, a imediatez, a publicidade, a imprevisibilidade e a história. O ambiente da classe, os estudantes, e mesmo a interação em aula, são elementos que acabam por influenciar a sociabilização dos novos docentes (MARCELO GARCÍA, 1999).

O terceiro, o "nível institucional", diz respeito às influências exercidas pelos atores sociais que compóem a instituição escolar onde o novo professor atua. Assim, se enquadram nesse contexto as relaçóes estabelecidas com gestores e colegas. Além disso, elementos como o currículo e as políticas da 
administração local afetam significativamente a sociabilização do novo docente, se enquadrando no nível em questão (MARCELO GARCÍA, 1999). O último nível, o social, é mais oculto e obscuro que os demais, visto ser composto por uma série de fatores que sáo desconhecidos ou ignorados, por vezes, pelos próprios sujeitos atuantes. Nesse contexto, são agrupadas questóes relativas à estrutura social, política e econômica em que a instituição se insere, que emana em seu funcionamento e comportamento geral exercido pelas partes atuantes (MARCELO GARCÍA, 1999).

Com base nestes níveis de influência e em outros condicionantes, Marcelo García (1999) conclui que a adequação dos novos professores à profissão depende de múltiplos fatores que se inter-relacionam, sendo ampliados ou diminuídos a depender dos aspectos específicos do sujeito. Compreendemos que aquele profissional que se encontra imerso à fatores positivos é impulsionado a socializarse e a dar continuidade à sua carreira, ao passo que um outro pode sofrer as imprecaçóes dos fatores opressores.

Assim como a socialização profissional dos docentes é pautada em distintas dimensôes (pessoal, institucional, de classe, social, entre outras), o abandono docente nesta fase de socialização também pode ser decorrente destas distintas dimensóes que se articulam e se intensificam. O estudo de Martinez (2016), por exemplo, evidencia esta premissa ao "avaliar as correlaçóes existentes entre as características dos docentes, da escola, dos diretores, além da percepção dos professores e do diretor, e da conjuntura econômica sobre a decisáo do professor de abandonar a rede pública estadual paulista" (p. 8). Muito embora este trabalho tenha sido efetuado em na rede estadual de ensino de Sáo Paulo, suas consideraçóes podem ser expandidas para outras localidades e níveis de ensino. Isso porque os elementos abordados se relacionam aos aspectos compartilhados pela categoria, independentemente do nível de atuação. Assim, mesmo na atuação de professores universitários, se observam fatores múltiplos que advogam a favor do abandono - conforme descritos por Martinez (2016) -, hierarquizados por meio da subjetividade e contexto do profissional.

A revisão bibliográfica que realizamos evidencia a quase inexistente literatura sobre o abandono da carreira docente universitária, o que também justificou o desenvolvimento deste estudo. As produçóes localizadas sobre a desistência do magistério da educação básica (CAMPOS, 1993; SANTINI, 2004; MARTINEZ, 2016; SILVA, 2018) destacam que ela é pautada pelas condiçóes de trabalho que evidenciam a competitividade, o individualismo, as múltiplas demandas, a falta de recursos, as rápidas mudanças, a desvalorização profissional, os baixos salários, o controle do trabalho e os sofrimentos. Santini (2004, p. 5), por exemplo, aponta que "para alguns professores houve indícios de esgotamento profissional devido às pressóes e tensões específicas do contexto laboral". Além 
disso, o autor expóe que para a grande maioria dos profissionais ouvidos, a vivência de desgaste emocional e física "experimentadas e acumuladas durante sua trajetória profissional, traduziram-se em sentimentos depressivos e de fadiga crônica, compondo um estado anímico, que aqui se denomina de Síndrome do Esgotamento Profissional" (SANTINI, 2004, p. 5). Supomos que estes achados também podem se evidenciar como motivos do abandono da docência superior.

Alguns estudos sobre a docência superior também evidenciam elementos que caracterizam o esgotamento profissional. Cislaghi (2011), por exemplo, ao tratar dos contextos das universidades públicas, traz à tona a limitada ampliação dos quadros docentes, o pouco investimento nas estruturas físicas das instituições, a atuação com turmas de alunos cada vez maiores, o arrocho salarial, a transformação do "professor em um empreendedor, por meio da venda de pesquisas e da prestação de serviços em parcerias público-privadas, captação dos fundos setoriais, entre outros mecanismos" (p. 171), "a demanda por múltiplas atividades: ensino, pesquisa - dentro do critério produtivista -, extensão - sobretudo por meio da venda de serviços - e administraçáo" (p. 171). A soma destes elementos é denominada pela autora como "precarização e superexploraçáo do trabalho docente" (p. 165), o que tende a afetaram o trabalho e o desenvolvimento docente.

Em nossa concepção, estes elementos contribuem com a desmotivação docente e o desinteresse pela profissão. $\mathrm{O}$ abandono docente é um ato final de um longo processo de elaboração, envolvendo todos os cálculos internos feitos pelos docentes a fim de alcançar tal decisão, por meio do emprego de mecanismos cognitivos, afetivos e socioemocionais. Neste trabalho abordamos o abandono docente definitivo, explicado por Carlotto, Câmara e Oliveira (2019) como aquele que é fruto do esgotamento de todas as tentativas de manutenção e permanência profissional.

Uma das tentativas para evitar o abandono do magistério superior seria o investimento em projetos institucionais de desenvolvimento profissional docente, especialmente junto aos profissionais que se iniciam na profissão. Compreendemos que as atividades apontadas por Marcelo García (1999), por exemplo, que incluem informaçóes escritas, visitas a instituiçóes de ensino, redução da carga docente, seminários de discussáo, contato com outros professores iniciantes, estudo de casos, mentoria, poderiam contribuir com a superação das adversidades da docência, potencializar aprendizados e colaborar com a permanência na profissão. Marcelo García (1999) e outros pesquisadores relatam experiências bem sucedidas de programas de indução profissional à docência desenvolvidas na Europa, o que, ainda, não tem sido uma prática recorrente no Brasil.

Tendo por base estas concepções de docência universitária, de educação superior, de ingresso e de abandono da carreira docente relacionadas aos distintos 
fatores apresentados, neste artigo objetivamos compreender os motivos do abandono da docência das professoras iniciantes na educação superior ${ }^{3}$. Para responder a essa questão particular, desenvolvemos uma pesquisa de abordagem qualitativa, a partir de um trabalho "com o universo de significados, motivos, aspiraçóes, crenças, valores e atitudes, o que corresponde a um espaço mais profundo das relaçóes, dos processos e dos fenômenos que não podem ser reduzidos à operacionalização de variáveis" (MINAYO, 1999, p. 21-22).

Trata-se de um estudo de caso sobre professoras em início de carreira que abandonaram a profissão em decorrência das adversidades enfrentadas. No caso estudado, investigamos a manifestação do fenômeno no contexto real e, com suporte em uma base teórica, buscamos "analisar a multiplicidade de dimensôes que [o] envolvem” (MARTINS, 2008, p. 10).

Para a coleta de dados empíricos utilizamos entrevistas que, segundo Szymanski (2004), já faz com que o entrevistador comece a refletir sobre os achados durante sua execuçáo, visto permitir uma proximidade com a realidade. As entrevistas foram guiadas por questóes que buscaram esclarecer, focar e aprofundar (SZYMANSKI, 2004) o tema e foram desenvolvidas de modo on-line ${ }^{4}$.

Enviamos e-mail e/ou mensagens por redes sociais para pessoas que sabíamos que tinham abandonado a docência, apresentando a pesquisa e convidando-as a colaborar com a pesquisa. Também fizemos contato com profissionais que nos foram indicados e que apresentavam o perfil buscado. Náo obtivemos retorno de todos nossos contatos. A partir dos convites feitos, tivemos a adesão e participação na pesquisa de cinco ex-professoras universitária que tiveram até 5 anos de experiência docente antes de se desligarem da profissão.

Coincidentemente, todas as pessoas que se dispuseram a colaborar foram mulheres, as quais receberam os seguintes nomes fictícios, para preservar suas identidades: Camila, Karine, Gerusa, Juliane e Paula ${ }^{5}$. Na tabela 1 apresentamos algumas informaçóes sobre o perfil profissional destas ex-professoras:

3 Recorte e aprofundamento de dados apresentados em: GIULIATO, Mauro Volney. Abandono docente de professoras iniciantes na Educaçáo Superior. 2020. Dissertação (Mestrado em Educação) - Programa de Pós- Graduação em Educação, Universidade do Oeste de Santa Catarina, Joaçaba, 2020.

4 As entrevistas, realizadas no mês de abril de 2020, ocorreram de forma on-line em razão da vigente pandemia de COVID-19.

5 A pesquisa foi aprovada pelo Comitê de Ética em Pesquisa da Universidade à qual pertencemos. Neste trabalho apresentamos um recorte aprofundado de parte da pesquisa apresentada ao Comitê. 
Tabela 1 - Informações sobre as colaboradoras

\begin{tabular}{|c|c|c|c|c|c|c|}
\hline Nome & $\begin{array}{c}\text { Formação } \\
\text { inicial }\end{array}$ & $\begin{array}{c}\text { Maior } \\
\text { Titulação }\end{array}$ & Universidade & $\begin{array}{l}\text { Carga } \\
\text { horária }\end{array}$ & $\begin{array}{l}\text { Exercia outra } \\
\text { atividade } \\
\text { profissional? }\end{array}$ & $\begin{array}{l}\text { Tempo na } \\
\text { docência }\end{array}$ \\
\hline Camila & Serviço Social & $\begin{array}{l}\text { Mestrado em } \\
\text { Política Social }\end{array}$ & $\begin{array}{l}\text { Privada } \\
\text { (filantrópica- } \\
\text { comunitária) }\end{array}$ & $\begin{array}{l}\text { De } 15 \text { a } \\
26 \text { horas } \\
\text { semanais }\end{array}$ & Sim & 3 anos \\
\hline Karine & $\begin{array}{l}\text { Medicina } \\
\text { Veterinária }\end{array}$ & $\begin{array}{l}\text { Especialização } \\
\text { em produção } \\
\text { de ruminantes } \\
\text { e da qualidade } \\
\text { do leite }\end{array}$ & $\begin{array}{l}\text { Privada } \\
\text { (comunitária) }\end{array}$ & $\begin{array}{l}6 \text { horas } \\
\text { quinzenais }\end{array}$ & Sim & 3 anos \\
\hline Gerusa & $\begin{array}{l}\text { Ciências } \\
\text { Biológicas }\end{array}$ & $\begin{array}{l}\text { Doutorado } \\
\text { em Biologia } \\
\text { de Ambientes } \\
\text { Aquáticos } \\
\text { Continentais }\end{array}$ & Pública & $\begin{array}{l}40 \text { horas } \\
\text { semanais } \\
(D E)\end{array}$ & Não & 4,5 anos \\
\hline Paula & $\begin{array}{l}\text { Ciências } \\
\text { Econômicas }\end{array}$ & $\begin{array}{l}\text { Mestrado em } \\
\text { Economia e } \\
\text { Desenvolvimento }\end{array}$ & $\begin{array}{l}\text { Pública e } \\
\text { privada }\end{array}$ & $\begin{array}{l}16 \text { horas } \\
\text { semanais }\end{array}$ & Não & 3 anos \\
\hline Juliane & $\begin{array}{l}\text { Letras - } \\
\text { Português e } \\
\text { Inglês }\end{array}$ & $\begin{array}{l}\text { Mestrado em } \\
\text { Letras }\end{array}$ & Pública & $\begin{array}{l}40 \text { horas } \\
\text { semanais } \\
(D E)\end{array}$ & Não & 5 meses \\
\hline
\end{tabular}

Fonte: Os autores, 2021.

Neste trabalho tomamos os relatos das ex-professores relativos à questão: Quais fatores somaram para seu abandono docente? Na resposta as colaboradoras expurgaram suas vivências, suas afliçóes e seus entendimentos dessa experiência de docentes universitárias. Na sequência apresentamos e analisamos estas respostas a partir de princípios da análise de conteúdo.

\section{Docência na educação superior, um sonho abortado}

De modo geral, observamos alguns motivos do abandono que podem se dizer comuns a algumas docentes. Porém, verificamos que o somatório de distintos motivos particulares a cada uma delas, envolvendo fatores profissionais e pessoais é que definiu o abandono. Em todo caso, e conforme exposto na literatura especializada, a decisão pelo abandono docente não ocorre da noite para o dia. Antes disso, esse ato deve ser compreendido como a etapa final de um longo processo de lutas, iniciado com a intenção de desligar-se da profissáo 
em decorrência de um cálculo dos fatores como os já mencionados, a partir "da avaliaçáo/satisfação do trabalho, alternativas de mercado e custos/benefícios da decisão de saída da profissão ou do local de trabalho" (CARLOTTO; CÂMARA; OLIVEIRA, 2019, p. 3).

Mesmo diante da feitura desse cálculo, há que se considerar que a decisão pelo rompimento não é fácil, visto que alguns dos docentes compreendem sua profissáo como sendo o alcance de algo que por muito tempo foi desejado. Junto a isto, o início da carreira docente na educaçáo superior, especialmente em instituiçóes públicas, representa, na maioria dos casos, o alcance de uma estabilidade, status e boa remuneraçáo, obtidos a partir de um árduo processo. Desse modo, decidir abandonar essa conquista é difícil, causa sofrimento ao sujeito - como evidenciado nas entrelinhas por Gerusa e Juliane. Apresentamos o seguinte depoimento, como exemplo:

[...] o que acontece, as pessoas se agarravam numa vaga na federal, assim, sabe? [...] "Ah, é a única chance que eu tenho e tal" [...]. Eu não tinha nem mestrado ainda, estava estudando . Eu disse "eu tô fazendo mestrado ainda, eu já consegui [...] depois que eu terminar isso aqui e terminar o meu mestrado, acha que eu não vou conseguir de novo?” (JULIANE)

Em sua fala, outra participante apontou a estrutura mercadológica da instituição como um dos elementos que contribuiu para o abandono:

[...] tem pessoas bem bacanas, com visáo bem aberta, tem! [...] Mas o teor da instituiçáo era [...] o lucro, [...] tratar o estudante como cliente. [...] Eu via que a gestora tratava como cliente. (CAMILA)

O modelo de atuaçáo que lhe era comunicado por seus superiores, o qual demandava desinteresse pela formação real do aluno diante de suas condicionantes sociais (idade, situaçáo financeira, social, de trabalho, etc.), gerava tristeza na docente, o que lhe fazia sentir-se mal. Neste aspecto, é importante lembrar o que é exposto por Cislaghi (2011), que argumenta que em decorrência de uma postura institucional voltada ao mercado e não propriamente à funçáo social do ensino, o professor se torna vítima de interesses produtivos da instituição.

6 No momento da entrevista Juliane já possuía o título de mestre. Nesta passagem ela se refere ao momento do seu concurso público. 
Apontamentos semelhantes também são apresentados por Bernardo (2006), Hoffmann; Zanini; Moura e Machado (2019) e Almeida (2018). Entendemos que isto dissocia o professor de sua função primária e amplia as cargas e sofrimentos impostos sobre ele.

Camila afirma, portanto, que diante de sua formação voltada ao serviço social, ela náo conseguia desconsiderar todo o contexto dos alunos, o que não era feito ou motivado pela instituição. Somado a isso, a entrevistada relatou que era a coordenadora do curso e como tal precisava resolver vários problemas e atender constantemente os alunos. Contou que vivia com medo das ameaças demissionárias da universidade, não conseguia dormir direito mediante a sensação de coisas por fazer, que se sentia sobrecarregada e angustiada, vivia correndo para conseguir conciliar questóes familiares (filhos) e de trabalho. Tudo isto a conduziu, inclusive, para o desenvolvimento de um quadro depressivo, acarretando-lhe o adoecimento e o uso de medicaçáo. Todos estes aspectos refletiram, invariavelmente, em sua recepçáo diante do desempenho de sua função, contribuindo negativamente para seus índices de felicidade diante de seu trabalho. Assim, Camila sentiu a necessidade do afastamento da docência, a fim de se preservar.

Karine indicou a ampliação para 40 horas semanais de seu outro vínculo de trabalho como o fator primário do seu abandono do exercício docente:

Até que eu trabalhava na prefeitura eu conseguia conciliar, conseguia acordar com o pessoal. Mas depois não teve mais essa. E como as aulas da Veterinária eram só durante o dia, eu não tinha como deixar meu trabalho para ir para outro lugar, porque eu faço 40 horas. Então daí complicou, [...] foi determinante, na verdade. [...] Eu não ficava muito tempo lá na instituição, na verdade [...] eu ia lá só para dar minha aula e saía. [...] Se eu tivesse tido mais envolvimento em outras matérias, [...] talvez umas matérias específicas, não só... [...]. A gente vai mudando e vai mudando o foco também. (KARINE)

Além disso, a entrevistada apontou a falta de envolvimento com a cultura da universidade como um elemento motivador de seu afastamento. Cabe lembrar aqui que Karine atuava 6 horas semanais de 15 em 15 dias na docência. Ela possuía uma baixa carga horária, o que não lhe permitia viver apenas com o salário de professora. Aliás, a docência não era a maior fonte de renda de Karine. Como resultado, seu trabalho docente era uma atividade complementar, secundária.

Bernardo (2006), em seu estudo, já chamou a atenção para o fato de que o trabalho docente como atividade complementar é um dos desafios vivenciados 
na educação superior. Karine, ao ser convidada a lecionar, aceitou o desafio por algum tempo, porém, com o aumento de sua carga horária em sua profissáo de origem, na qual tinha sua identificaçáo profissional, optou pelo abandono docente. Este artificio de ver a docência em segundo plano deixa evidente as tensóes e a insegurança de uma cultura organizacional hostil. Geralmente, quando algo desperta encantamento, faz com que as pessoas queiram viver aquilo, deixando outras atividades a fim de dar conta e suportar as intempéries inerentes. $\mathrm{O}$ oficio docente náo causou este encantamento em Karine.

Nas declaraçóes de Gerusa, a entrevistada separa os fatores de seu afastamento em duas áreas: fatores profissionais e fatores pessoais - os quais também são identificados em estudos de Marcelo García (1999) e de Isaia, Maciel e Bolzan (2010). A ex-professora relatou:

$\mathrm{Na}$ questão profissional, uma delas [...] eu via que alguns docentes dentro da instituiçáo conseguiam se estabelecer dentro de uma área de ensino e de pesquisa. E outros náo, como eu. Aí eu brincava que eu era um professor tapafuro. Estava faltando professor de disciplina "tal", coloca fulano, faltou disciplina "tal"... Então eu náo conseguia me estabelecer como professora no ensino superior. Ao mesmo tempo eu era cobrada para fazer pesquisa, para fazer extensão, que é o papel do professor universitário, também. [...] E a questáo pessoal também, porque [...] eu estava na universidade, eu estava num outro lugar, eu não me inseri tanto na cultura local [...]. Apesar da gente estar dentro do mesmo estado, eu notei diferenças, bastante diferenças entre as duas cidades [...]. Então a minha vida pessoal, minha família estava [em outro lugar]. Passei por situaçóes de doenças com meus pais, tratamentos, e eu estava distante, ficava indo e vindo muito [...], são 10 horas de ônibus. Eu fazia isso toda semana. Tinha a questão de, na época meu namorado, agora meu marido que também estava em outra cidade. Então, esse lado pessoal pesava muito. Ficou cada vez mais difícil [...]. Acho que foi esse conjunto, sabe? (GERUSA)

Em referência aos fatores profissionais, Gerusa aponta o fato de não poder lecionar apenas em sua área - o que lhe dava a impressão de ser um professor "tapa-furo" -, como sendo algo que dificultava sua atuação. Ela não conseguia se estabelecer como professora universitária, especialmente por não conseguir desempenhar outras funções atreladas à carreira, como pesquisa e extensão. A entrevistada relatou que relevou algumas práticas institucionais em razão de sua 
condição de iniciante na universidade. Contudo, ao perceber que a situação não era alterada com o passar dos anos, o abandono foi a única saída viável.

Além disto, diferentemente do que ocorria com ela, alguns de seus pares conseguiam atuar apenas em sua área, tinham uma carga de ensino diminuída e podiam dedicar-se às atividades de pesquisa e extensão. Gerusa atribuiu às relaçóes de política interna o surgimento de um ambiente tóxico que poderia afetar sua saúde mental. Indicamos, portanto, que a docente se desestimulou pelo seu crescimento profissional de docente naquela instituiçáo. A entrevistada aponta ter sofrido, inclusive, assédio moral de superiores (refletido apenas posteriormente), diante de um contexto de concorrência de seus pares.

No contexto pessoal, a entrevistada apontou dificuldade de inserção na cultura local, especialmente por ter sido necessário mudar-se para outra cidade, mantendo sua vida pessoal em sua cidade de origem (com distância de dez horas por via terrestre). Além disso, elementos como situaçóes de doenças familiares, a distância do parceiro romântico, a condição de ser bastante jovem e o consequente quadro de tristeza contribuíram para a tomada da decisáo de abandono - o que, segundo ela, foi uma decisão muito difícil.

É importante lembrar Marcelo García (1999), que pondera que a socialização profissional docente é, entre outros, influenciada tanto pelo nível profissional (que envolve aspectos da instituição, das relaçóes estabelecidas com gestores e colegas, do currículo e das políticas da administração local) quanto pelo nível de influência pessoal (definido pelas experiências biográficas pregressas do sujeito bem como pela experiência vivenciada no momento de sua formação para ser professor). Estes níveis e suas caracterizaçóes ficaram bastante evidentes no relato de Gerusa. Sua fala retoma a percepçáo de que no ciclo profissional docente e no processo de socialização existem várias esferas que se intercruzam e codependem, embora ainda se caracterizem como elementos distintos. É evidente, contudo, que cada elemento carrega as idiossincrasias de cada sujeito específico, além de serem influenciados pela forma como o indivíduo interpreta os acontecimentos por ele experimentados.

Antes de tratar dos fatores que se somaram para o abandono docente de Paula, cabe mencionar que ela atuou na universidade pública com contrato temporário e em instituição privada. Portanto, ela realmente desistiu da docência motivada por fatores de sua experiência profissional na instituição privada - visto que sua atuação na instituição pública tinha previsão de término. O principal motivo do abandono docente de Paula foi a baixa remuneração - a instituição pagava apenas as horas diante dos alunos, desconsiderando o tempo de preparo de aula e de correção de atividades. Isso lhe fez pensar na opção de reestruturar sua carreira a partir de outras possibilidades de trabalho. A pesquisa motivou a entrevistada a ingressar na carreira docente, porém ela não conseguiu desenvolvê-la naquele 
momento, em razão da falta de tempo. Ainda, a sobrecarga de trabalho e o receio de que a má reputação da instituição privada (e de seus gestores) pudesse ser transferida para ela atuaram no desestímulo de sua atuaçáo como docente. Retratamos aqui um recorte do que foi evidenciado:

É uma instituição bem pequenininha e começou a passar por problemas financeiros gravíssimos [...]. Até mesmo por ser pequena, entâo qualquer coisa que falte afeta muito a instituição. [...] Aí eu cheguei num ponto que eu pensei assim "gente, será que trabalhando nessa instituição eu não estou na verdade sujando o meu nome? [...] Será que não está ficando feio eu trabalhar nessa instituição?” Eu comecei a pensar, "será que eu me apresentar como professora desse lugar é legal? [...] eu acho que é feio eu dizer que trabalho nesse lugar, então não vou mais trabalhar nesse lugar”. (PAULA)

A fala de Paula repercute a já explorada condição precária do trabalho docente, algo que, em grande medida, está relacionado à condição mercadológica das instituiçóes (CISLAGHI, 2011; BERNARDO, 2006; HOFFMANN; ZANINI; MOURA; MACHADO, 2019; ALMEIDA, 2018; PIMENTA; ANASTASIOU, 2002). De forma pontual, contudo, observamos na fala da entrevistada questóes relativas à má remuneração, elemento que comumente surge em estudos relativos ao abandono docente na Educação Básica, como o estudo de Silva (2018). Essa má remuneração, observada no relato da Paula, é comumente presenciada em contratos de professores aulistas, sem forte e restrito vínculo com as instituiçóes de educaçáo superior.

No relato de Juliane, notamos que o fator principal que a conduziu ao abandono é descrito como sendo a relação de opressáo estabelecida por alguns de seus pares que exerciam cargos superiores. Além disto, de modo geral, sentiuse mal pela competição e politicagem na relação com os colegas professores, conforme se observa nessa narrativa:

[...] Questôes políticas, da instituição. [...] eles fizeram de tudo para dificultar a minha vida [...] achando que tu é capacho deles. [...] "Ah, quer saber, vou embora daqui". Foi uma época muito turbulenta, exatamente por estes relacionamentos. Na sala de aula era tri bom, dar aula, os alunos interessados, os projetos dando certo. Mas quanto à relaçáo com outros, com os superiores, ver o jeito que eles tratavam os técnicos também [...] Eu até perguntava "quando que eu vou tirar férias?" Ela dizia: "eu também 
não sei [...] porque no período letivo normal, tu dá aula pra um curso, e nas férias tu vai dar aula pra Educação do Campo". E eu "tá, e quando é que eu tiro férias?". "Ah, não sei, a gente vai ter que ver, tipo cinco dias, dez dias, e tu vai tirando aos pouquinhos." (JULIANE)

Assim como Gerusa, Juliane também sentiu que alguns colegas eram favorecidos em algumas tomadas de decisóes.

Quatro colaboradoras (Camila, Karine, Gerusa e Juliane) haviam exercido anteriormente atividades profissionais em suas áreas de formação (respectivamente: Serviço Social, Medicina Veterinária, Ciências Biológicas e Letras/Intérprete), o que contribuiu para uma percepção de estabilidade prévia. Paula foi a única que relatou que se inseriu na docência universitária logo após a conclusão do mestrado. Ainda, Juliane evidenciou em seu relato que gozava de uma vida financeira estável, o que também pode ser considerado basilar para sua decisão de abandono. É possível observar, desse modo, a existência de condição prévia de sustento financeiro como um elemento facilitador do processo de abandono docente na educação superior, especialmente quando o sujeito possui formação que lhe permita, antes de dar início à carreira docente, atuar em completo afastamento do ambiente acadêmico.

Muitos dos elementos apontados pela literatura especializada como condicionantes do abandono docente da Educação Básica foram observados, mesmo que em menores ou maiores proporçóes, no depoimento das entrevistadas. Exemplos dos fatores que levam ao abandono podem ser a precarização do trabalho, a baixa disponibilidade de recursos e a baixa remuneraçáo, a exemplo do que já sinalizaram Campos (1993), Santini (2004) e Martinez (2016). A questão da precarização do trabalho docente e/ou as condiçóes de trabalho, de modo direto ou indireto, aparecem na fala de todas as entrevistadas.

Ademais, a estrutura mercadológica na qual as universidades se inserem, comumente, na contemporaneidade (CISLAGHI, 2011; BERNARDO, 2006; HOFFMANN; ZANINI; MOURA; MACHADO, 2019; ALMEIDA, 2018; PIMENTA; ANASTASIOU, 2002) foi um elemento observado na fala das colaboradoras. Tal estrutura é marcada por uma noção, por parte da instituição, de enxergar os alunos como simples clientes, desconsiderando seus contextos e necessidades reais - bem como o objetivo real de ensinar.

Essa visão mercadológica imputa ao docente uma sobrecarga, motivada pelo interesse na obtenção de lucros. Esta estrutura também gera a concorrência entre os profissionais, ocasionando politicagens internas que criam um ambiente profissional, por vezes, opressivo. Estas pressóes, somadas a diversos outros fatores, criam um ambiente tóxico (se valendo da fala de uma entrevistada) que 
precariza a dinâmica do trabalho, produzindo quadros de tristeza, angústia e, ocasionalmente, de depressão. Assim, ao ter que optar pela manutençáo de sua sanidade e a continuidade do cargo, tais docentes acabam por escolher evadir-se.

Em última instância, os relatos afirmam que o ambiente da docência muitas vezes dificultava o desenvolvimento de um trabalho cooperativo e coletivo. A atenção à melhoria de tais aspectos propiciaria o desenvolvimento de indivíduos mais felizes inseridos em ambientes mais nutritivos e dispostos aos mais amplos aspectos de desenvolvimento humano.

Interessante perceber que a atividade de ensino em sala com os alunos não foi fator primeiro de nenhuma entrevistada para o abandono. De certa forma, esta constatação desafia o mito que se tem de que a atividade docente é "dar aulas”. Este mito pode ser tensionado ao se observar as razóes para o abandono docente foram observadas em outros aspectos subjetivos da docência. Apesar do ensino imediato em sala de aula não ter motivado diretamente o abandono, podemos compreender que, a partir de uma visão mais ampla, ele o motivou, pois, o processo ou as demais demandas do ensino influenciaram sobre a decisão do abandono. Por exemplo, assumir distintos componentes curriculares, sobre os quais não se tem domínio teórico, exige do professor uma dedicaçáo de horas de estudo e planejamento. Isto causa, minimamente, sobrecarga e ansiedade. Estes sim são fatores decisórios para o abandono.

Diante dos inúmeros desafios (de trabalho, pessoais e de saúde) as cinco colaboradoras priorizaram sua sanidade geral frente ao sucesso profissional/ financeiro. Tal aspecto fica mais evidente nos casos de Gerusa e Juliane, que eram professoras concursadas de universidades federais e, ainda assim, decidiram abrir mão deste cargo tão almejado, tendo em vista os mais diversos condicionantes que precarizavam os outros aspectos de sua vida cotidiana.

Não menos importantes, observamos também que fatores pessoais e subjetivos atuaram de forma relevante na tomada da decisão pelo abandono docente. Notamos, por exemplo, que a inadequação à cultura da universidade, a mudança da localidade de residência e a distância estabelecida entre o indivíduo e sua vida social-familiar foram fatores que contribuíram para a desistência da carreira. A desistência, nesses casos, representa o retorno para o seu meio, para seu estado de tranquilidade. Algo compreensível, considerando que, no processo de socialização e adaptação à nova carreira, várias esferas se intercruzam e codependem, como já destacado por Marcelo García (1999) e Isaia, Maciel e Bolzan (2010). Portanto, o desligamento da carreira ocorreu por adversidades tanto profissionais quanto pessoais.

Quando o docente concretiza a ideia da não permanência como docente universitário, também concretiza a dissolução de vínculos afetivos. Logo, observamos uma abrupta descontinuidade e, por mais que na apresentação 
inicial da instituição, dos pares e dos alunos tudo lhe tenha parecido interessante, o todo agora passa a ser visto como pouco amistoso. Sáo, assim, rompidos os já fragilizados vínculos e motivos para estar ali, em todas as esferas. Assim, toda expectativa vai se transformando em frustração, de pronto é mudado o foco de investimento dos recursos afetivos, profissionais, criativos e sociais deste indivíduo, que passa a investir em algo que lhe pareça mais atrativo e prazeroso.

Em um balanço feito pelas ex-professoras, há uma confirmação de que o exercício da docência não lhes dava mais a satisfação e o bem-estar capazes de mantê-las no cargo. Interessante destacar que as professoras pesquisadas tinham distintas formaçóes e atuavam em diferentes áreas e instituições, porém este balanço levou ao mesmo resultado para todas: o abandono. Em última instância, a docência não mais lhes proporcionava felicidade. Isso faz lembrar que, especialmente nas últimas décadas, a noção de felicidade - em seus atuais modos, é claro - ganha valor indiscutível e indissociável na vida humana. Logo, tal aspecto possui peso considerável no balanço da escolha pelo desempenho e manutenção das atividades de um determinado sujeito, conforme refletem estudiosos como Ferraz, Tavares e Zilberman (2007).

\section{Apontamento e desenlace, um olhar dos relatos das ex-professoras}

A decisão pelo abandono da docência foi sendo construída pelas docentes, foi o fim de um processo de sofrimentos e de poucas realizaçóes profissionais comparadas às frustraçóes. Pareceu-nos que existe uma equivalência nos relatos das entrevistadas iniciado pelo sofrimento físico e mental, seguido de desinteresse e do abandono propriamente dito. A decisão pelo abandono foi resultado de um longo processo de elaboração, de cálculos internos, por meio do emprego de mecanismos cognitivos, afetivos e socioemocionais. Nos casos pesquisados, a soma de vários fatores levou cada uma a desistir da carreira.

Os motivos do abandono se referem aos distintos níveis da socialização e da construção da identidade docente apontados por Marcelo García (1999): pessoal, institucional, da classe e social. Ou seja, as professoras iniciantes se desligaram da profissão em decorrência de adversidades profissionais e pessoais. Os motivos citados perpassaram: relaçóes de superioridade entre os pares e gestores, dificuldades em conseguir desempenhar as funçóes que almejava, falta de tempo, sobrecarga de trabalho, má reputação da instituição, quadro de tristeza, dificuldades de inserção na cultura local, o distanciamento físico entre a vida profissional e a vida pessoal, entre outros. Todos esses motivos desvelam também a complexidade da etapa do início de carreira (NUNES; CARDOSO, 2013). 
Reforçamos aqui a necessidade de um olhar atento a dimensão pessoal do professor que ingressa na carreira, pois a falta de satisfação e o não se sentir bem no ambiente de trabalho incidem fortemente na decisão do abandono. Retomamos, também, a ideia de que o trabalho não é apenas um "ganha pão", é algo que precisa dar sentido à vida. Portanto, a permanência na docência é firmada para além de aspectos institucionais e pedagógicos: a permanência na profissão está relacionada com a felicidade do ser humano.

Esses quatro níveis - pessoal, institucional, da classe e social - se intercruzam e juntos determinam a qualidade da socialização do docente. Considerando que o processo de socialização é essencial para o desenvolvimento da identidade docente, o desinteresse ou a negligência de seus elementos proporciona rupturas no desenvolvimento da identidade do professor iniciante. Como resultado, esses docentes se mostram mais propensos ao abandono, visto não ter se socializado com o meio e ali criado raízes. Logo, aquilo que aparenta ter caráter pessoal, pode também ser de ordem profissional, o contrário também é válido.

Os motivos do abandono da docência superior evidenciados nesta pesquisa são próximos dos motivos apontados em outros estudos que abordaram o abandono da docência na Educação Básica. O que é comum nesta e naquelas pesquisas é a ênfase do motivo da precarizaçáo do trabalho docente. Contudo, a presente pesquisa considera que o que conduz à precarizaçáo diverge consideravelmente de um nível para o outro, como nos quesitos do prestígio e da remuneração, visto que ainda há posiçôes de relevância distintas entre os níveis.

Por mais que a instituição superior supostamente detenha melhores condiçóes estruturais e de trabalho, quando os professores são tratados como tarefeiros ou horistas, deixa-se de enaltecer o que é crucial para o desenvolvimento docente. Quando o professor náo se sente inserido e cuidado, ele percebe que para a instituição ele é um trabalhador qualquer; ele percebe que seu trabalho pode ser feito por qualquer outro indivíduo. Este e outros fatores já mencionados corroboram para a precarização, o desgaste e a consequente evasão docente.

$\mathrm{O}$ elemento que melhor caracteriza o pano de fundo do abandono docente das ex-professoras iniciantes na educação superior é a adequação das Instituições de Ensino Superior a uma estrutura mercadológica - mesmo no que diz respeito às instituições públicas. Nesta lógica, muitas vezes os alunos são vistos como clientes e a instituição como uma simples fornecedora de um produto. Assim, questôes humanistas, relativas às necessidades socioeconômicas e culturais dos discentes muitas vezes não estão ao alcance dos professores.

Esta lógica também afetou a relação das docentes com seus pares e superiores. Observamos a concorrência e competitividade entre os pares e uma relação opressiva com os superiores pautadas, por vezes, em açóes evidentes de clientelismo. Atrelado ao mercado também está a condição de sobrecarga, 
amplamente comentada e mencionada como elemento central do processo de abandono das docentes entrevistadas. Constatamos que algumas delas eram lançadas em um ambiente tóxico que deteriorava suas autoimagens e suas identidades, que exigia suas adequaçôes a custo de suas sanidades física e mental. Nos casos estudados, o caminho viável diante de tais provocaçóes foi o abandono da carreira.

É preciso pensar em mudanças ante este quadro do abandono docente, a fim de evitá-lo e de que a evasão seja mitigada, a fim de ampliar a qualidade da educação superior. Fica evidente a necessidade de melhor acompanhamento das professoras que ingressam na docência superior e a necessidade de elaboração de propostas formativas que favoreçam a constituição identitária destas profissionais e a construção de um ambiente de trabalho favorável, menos tóxico, menos mercadológico e menos competitivo. Para tal, seria possível, por exemplo, programas de desenvolvimento profissional para os docentes iniciantes pautados no apoio pedagógico por parte de professores seniores, na constituiçáo de grupos de trabalho ou rodas de conversas entre professores, entre outros.

A ausência de iniciativas que visem sanar estas necessidades significa, consequentemente, a desvalorizaçáo do desenvolvimento profissional docente. Ou seja, a partir dos resultados deste estudo defendemos uma cultura institucional que valorize seus professores e suas permanências na docência superior.

\section{Referências}

ALMEIDA, M. I. de. Fundamentos pedagógicos e didáticos da prática docente universitária e o lócus privilegiado para o seu desenvolvimento. In: MARIN, Alda Junqueira; PIMENTA, Selma Garrido. (orgs.) Didática: teoria e pesquisa. 2. ed. Araraquara: Junqueira \& Marin, 2018, p. 125-140.

BERNARDO, M. A. B. Desafios da Educaçáo Superior na atualidade: trajetórias docentes. Campinas, 2006. Dissertação (Mestrado em Educação) Pontifícia Universidade Católica, Campinas, 2006.

BRASIL. Lei n. 9.394, de 20 de dezembro de 1996. Estabelece a Lei de Diretrizes e Bases da Educaçáo Nacional. Disponível em: http://portal.mec. gov.br/arquivos/pdf/ldb.pdf. Acesso em: 27 fev. 2020.

CAMPOS, V. L. S. L. Causas do desânimo e abandono dos professores das séries iniciais do Ensino Fundamental: representação social. 1993. Dissertação (Mestrado em Educação) - Universidade do Estado do Rio de Janeiro, Rio de Janeiro, 1993. 
CARLOTTO, M. S.; CÂMARA, S. G.; OLIVEIRA, M. E. T. de. Intenção de abandono profissional entre professores: o papel dos estressores ocupacionais. Revista Brasileira de Educaçáo, Rio de Janeiro, v. 24, p. 1-18, ago. 2019. Disponível em: https://www.scielo.br/pdf/rbedu/v24/1809-449X-rbedu24-e240028.pdf. Acesso em: 01 set. 2019.

CISLAGHI, J. F. Precarização e superexploração do trabalho docente: a expansão das matrículas e o aumento da relação professor/aluno. Universidade e Sociedade, Brasília, v. 20, n. 47, p. 165-174, fev. 2011. Disponível em: http://www.andes. org.br/img/midias/900296cf72461419b4954e9ddf0ee52e_1548263939.pdf. Acesso em: 01 set. 2019.

FELDKERCHER, N. Docência universitária: o professor universitário e sua formação. Práxis educacional, Vitória da Conquista, v. 12, n. 22, p. 221-245, mai./ago. 2016. Disponível em: https://periodicos2.uesb.br/index.php/praxis/ article/view/891/758. Acesso em: 05 dez. 2019.

FERRAZ, R. B.; TAVARES, H.; ZILBERMAN, M. L. Felicidade: uma revisão. Revista de Psiquiatria Clínica, São Paulo, v. 34, n. 5, p. 234-242, fev. 2007. Disponível em: https://www.scielo.br/pdf/rpc/v34n5/a05v34n5.pdf. Acesso em: 20 nov. 2019.

HOFFMANN, C.; ZANINI, R. R.; MOURA, G. L. de; MACHADO, B. P. Prazer e sofrimento no trabalho docente: Brasil e Portugal. Educaçáo e Pesquisa, São Paulo, v. 45, e1872632019, p. 1-20, 2019. Disponível em: http://www. scielo.br/scielo.php?script=sci_arttext\&pid=S1517-97022019000100570\&lng= pt\&nrm=iso. Acesso em: 05 dez. 2019.

ISAIA, S. M. de A.; MACIEL, A. M. da R.; BOLZAN, D. P. V. Educação superior: a entrada na docência universitária. 2010. In: REUNIÃO ANUAL DA ANPED, 33., 2010, Caxambu. Anais... Caxambu: Anped, 2010. p. 1-16.

MARCELO GARCÍA, C. Formaçáo de professores: para uma mudança educativa. Tradução: Isabel Monteiro. Porto: Porto Editora, 1999.

MARTINEZ, V. M. Quem sáo os docentes que “evadem”? Uma análise das características relacionadas ao atrito docente na rede estadual de Sáo Paulo. Ribeirão Preto, 2016. Dissertação (Mestrado em Economia) - Universidade de São Paulo, Ribeirão Preto, 2016.

MARTINS, G. A. Estudo de caso: uma reflexão sobre a aplicabilidade em pesquisas no Brasil. Revista de Contabilidade e Organizaçóes, São Paulo, v. 2, n. 2, enero-abril, p. 8-18, 2008. Disponível em: https://www.redalyc.org/ pdf/2352/235217215002.pdf. Acesso em: 02 set. 2021. 
MINAYO, C. de S. Ciência, técnica e arte: o desfio da pesquisa social. In: MINAYO, Cecília de Souza (org.) Pesquisa Social: teoria, método e criatividade. Petrópolis, RJ: Vozes, 1994. p. 9-29.

NUNES, C.; CARDOSO, S. Professores iniciantes: adentrando algumas pesquisas brasileiras. Formaçáo Docente: Revista Brasileira de Pesquisa sobre Formação de Professores, Belo Horizonte, v. 5, n. 9, p. 66-80, 5 jul. 2018. Disponível em: https://revformacaodocente.com.br/index.php/rbpfp/article/ view/96/85. Acesso em: 02 set. 2021.

PIMENTA, S. G.; ANASTASIOU, L. das G. C. Docência no Ensino Superior. São Paulo: Cortez, 2002.

SANTINI, J. A síndrome do esgotamento profissional: o "abandono" da carreira docente pelos professores de educação física da rede municipal de ensino de Porto Alegre. 2004. Dissertação (Mestrado em Ciências do Movimento Humano) - Universidade Federal do Rio Grande do Sul, Porto Alegre, 2004.

SILVA, A. P. da. Professores iniciantes egressos do curso de pedagogia e o abandono da carreira docente no município de Rondonópolis/MT. Rondonópolis, 2018. Dissertação (Mestrado em Educação) - Universidade Federal de Mato Grosso, Rondonópolis, 2018.

SZYMANSKI, H. Entrevistas reflexiva: um olhar psicológico sobre a entrevista em pesquisa. In: SZYMANSKI, Heloisa (org.) A entrevista na pesquisa em educação: a prática reflexiva. Brasília: Liber Livro Editora, 2004. p. 9-64. 